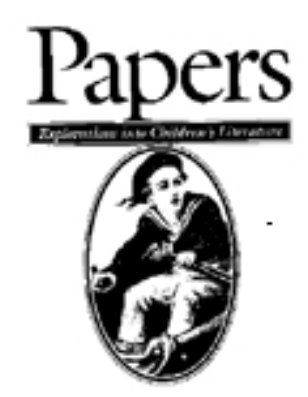

\title{
Twentieth Century Literature and Publishing Archives: UK Research Perspectives on Children's Literature
}

\author{
Charlotte Berry
}

\section{The University of Edinburgh}

British children's literature during the $20^{\text {th }}$ century has a robust pedigree and reputation, with many internationally acclaimed authors and texts included within its realm. However, publishing archives and children's literature archives have a low profile and use in the UK in both curatorial and research terms, resulting in huge untapped potential for researchers. Little has been published about modern publishing and children's literature archives, and this paper seeks to begin to address this gap within the current academic discourse.

This article is intended to constitute a starting point for those wishing to engage in study in this particular area of research by providing a contextual and historical background to the provenance and accessibility of $20^{\text {th }}$ century literary and publishing archives in the UK. This paper is based on current $\mathrm{PhD}$ research into the translation of Nordic children's literature in the UK, combining academic interests in children's literature and publishing history with professional expertise in the curation of literary and business archive collections.

\section{Children's Literature Archives and Research in the United Kingdom}

British academic interest in children's literature, although much increased in recent decades, remains surprisingly low for a country with such a rich literary heritage. Traditionally, children's literature in the UK has primarily been the concern of teachers and librarians, and this is still reflected in the fact that at least three of the few academic departments in the UK are based in departments of education or within a university which has origins as a teacher training college. There is inadequate representation of children's literature nationally within departments of English Literature. Research activities and research methodologies in children's literature and its allied fields are woefully under-developed with much room for future progress by researchers, teachers and information professionals.

In 2005, Newcastle became the home of Seven Stories, the first specialised archive and museum for British children's literature which actively collects British children's literature manuscripts and artwork (collections include those of Enid Blyton, Kaye Webb, Eva Ibbotson, Philip Pullman, Judith Kerr, Diana Wynne Jones and Robert Westall). The archive has a close relationship with the 
Children's Literature Unit in the Department of English at the University of Newcastle and arranges an active programme of events and exhibitions, as well as making its collections accessible to the local and research community. In terms of a dedicated approach to the active collecting of archives relating to British children's literature, this very recent and welcome development replaces the previously very ad hoc pattern of deposit of literary manuscripts relating to children's literature across the UK. It would appear that no national surveys of specifically children's literature collections have been undertaken to date.

Collections of literary and artistic importance that have already been deposited are held in a wide range of institutions, with much research still to be done on documenting the sometimes unpredictable provenance and history of these archives. Most typically, children's literary papers are to be found in university libraries where an author (or their literary estate) chooses to deposit a collection in an institution with which they have a particular affiliation or where curatorial staff have built up a positive depositor relationship (eg Kevin Crossley-Holland, Arthur Ransome, University of Leeds; Ted Hughes, David Rees, Charles Causley, University of Exeter; Brian Patten, Roger McGough, University of Liverpool; A A Milne, Trinity College Cambridge; Alison Uttley, John Rylands University; Alan Garner, Kenneth Graham, Bodleian Library). Local repositories are less common places of deposit (eg George MacDonald, Huntly Branch Library, Aberdeenshire; Robert Swindells, West Yorkshire Archive Service - Bradford).

Collections may alternatively be held at national institutions (Mollie Hunter, National Library of Scotland; Eleanor Farjeon, Lewis Carroll, British Library, E H Shepard, Victoria \& Albert Museum), although children's literature collections are vastly underrepresented here. More unusually, a specialist repository may be set up if an author's estate or literary profile is sufficient to support this (eg Roald Dahl, Beatrix Potter).

Identifying the location of such children's literary collections scattered in such an ad hoc pattern throughout the UK can sometimes be a protracted process. Online catalogues relating to UK archive collections as a whole are diverse and fragmentary in nature, varying in the extent of coverage and scope included. However, databases such as the National Register of Archives, the Archives Hub and the Literary Location Register of English Manuscripts serve as a useful overview of literary and publishing papers held within the UK. There is also a small number of specialist online databases relating specifically to archives of the British book trade (see below), but in general terms all of these databases only represent a fraction of the archive collections held in public and private hands. A lack of sustained investment in specialised staff and in maintaining such databases also means that catalogue data can be substantially out of date, with new accessions or newly catalogued collections radically under-represented. Therefore, a considerable amount of detective work and persistence are necessary in order to locate collections of relevance in children's literature research. 
Visibility and (Non) Use of Archive Collections Relating to Children's Literature and Publishing History

If not always straightforward to identify and use, British children's literature and publishing archives collections are without doubt immensely rich and diverse, especially for the twentieth century. It is therefore worth planning a project thoroughly in order to map out the available sources and to reap the benefits later on during actual research.

At the present time, the challenges of this process are not helped by the fact that very little published research addresses the difficulties of undertaking original literary research, whether written by academics (often expert in one particular period) or by curatorial professionals (who typically have a good overview of all UK book and archive collections and who also have a very detailed knowledge of the particular collections held within their professional care).

In the UK, few handbooks are available on undertaking general literary research, although those that exist do contain very relevant information for those engaged exclusively in children's literature. These include Sousa Carrea (2010), Denman-West (1998) and Eliot and Owen (1999). The choice encompassing children's literature alone is much narrower and this area is in need of some future attention. Thimble Press (edited by Nancy Chambers) published two short publications by Chester in 1989, which introduced the reader to the basics of commencing academic research in children's literature. Despite the considerable increases in research in children's literature since 1989, these pamphlets have not been superseded until the recent publication of Grenby and Reynolds' extremely useful introductory research handbook (2011). As well as covering the basics of varying theoretical approaches to children's literature, this handbook also includes tantalisingly short sections on locating and using primary and secondary sources, as well as general advice on undertaking research projects.

From this brief list of guidance available for literary research, it can be concluded that the value of literary research into children's literature is underestimated and/or that relevant archives are rarely used systematically as a research tool within the field. All possible factors for this trend have not been extensively considered in this paper, but it seems reasonable to assume that a lack of awareness of their potential and availability of children's literature sources must be a key point in their very low profile within the research community. Twentieth century publishing archives are similarly sidelined as a potential treasure trove of data relating to many aspects of children's literature and book/publishing history.

A brief examination of the available published literature reveals that publishing and book history academic journals primarily focus on the pre-twentieth century publishing scene, with only very occasional mention made of children's literature. Although general histories of twentieth century publishing history are beginning to emerge, children's literature is thus far excluded or barely considered. Similarly, journals and monographs encompassing children's literature in a historical context rarely make obvious use of archival sources and only seldom explicitly cite specific use bibliographical sources. Dudley Edward's significant history of children's literature during World 
War Two merely references the book trade serial The Bookseller as a data source alongside print histories of publishing houses, making no acknowledgement of archival sources in his 'Sources, guides and regrets' (Dudley-Edwards 2007, p.696). It seems remarkable that such a history could be written without consultation of publishing archives of some sort. A welcome but rare example of high quality and extensive use of archive collections is Holman's 2008 history of WW2 (nonchildren's) book publishing in England, which draws heavily on publishing archives held at the Universities of Oxford, Bristol and Reading, as well as collections at the National Archives and elsewhere. Perhaps unsurprisingly, Holman undertook a three year archival study as a Leverhulme Research Fellow based at the University of Reading, where England's most extensive publishing and printing collections are held.

Another contributory factor to low use of archives in this area of research is the relative newness of the fields of book history and publishing history in an academic setting. A noted above, general textbooks on publishing, bibliography, publishing history and book history typically make no mention of the benefits of archival research when studying developments within the British book trade and publishing. However, centres for research in publishing and book history are now becoming more commonplace in UK universities, having previously been partially the preserve of library schools (perhaps as a result of their specialisms in codicology and bibliography).

Research into nineteenth century and earlier publishing practices is now more widespread, with resources available such as the British Book Trade Index (covering firms and individuals trading by 1851), the Scottish Book Trade Archive Inventory (up to 1850) and the British Book Trade Archives Location Register (1830-1939). However, no equivalents are currently available covering the British book trade for the period post 1939, although the Edinburgh History of the Book in Scotland does continue its coverage up to 2000. In general terms, these useful resources do not cover the twentieth century, meaning that it is difficult to locate relevant archival collections and that their potential is not flagged up to the research community. However, printed company histories of publishing houses covering the twentieth century are available as a potential limited means of entry to locating relevant archive collections relevant to children's literature.

\section{Company Histories of Publishing Houses}

To date, the only extensive body of literature relating to the history of the publishing industry can be found in the numerous printed company histories of specific publishing houses, although once again the representation of children's literature is often very limited. These histories are often commissioned by the house in question, serving typically as a means of positive marketing by demonstrating the quality of the heritage lineage of the publishing house and its authors. As Hannah observes, "archival research often remains a major commitment [of a publisher] only when it derives from a commission to write a single company history, based on the (sometimes closed) archives of that institution" (2008, p.13).

Where heavily based on primary archival resources held by the company or elsewhere, full citations of the location and nature of these sources are not often given, once again making it difficult for 
subsequent researchers to track down primary sources of relevance. From the researcher's perspective, it is precisely the "randomness of record survival" which motivates the "lucky ones [who] come across a whole series of documents or indeed entire archives previously lost to research" (Pearson 2008, p.20). It could be argued that the full acknowledgement of the company's archive as a research resource is also subject to randomness.

Recent examples of business histories of major publishers with active children's lists include the recent Puffin by design: 70 years of imagination 1940-2010. Here Phil Baines (2010) gives a visual overview of the development of the Puffin list over its first 70 years. Although evidently drawing on the Puffin archive held at the University of Bristol, it makes no explicit reference to the collection throughout the book or in the acknowledgements, despite the fact that extensive use is made of images of manuscripts taken from the Puffin archive collection (the same can be said for the earlier Fifty Penguin years(Penguin Books 1985)). Similarly, although oral history interviews with past and present company employees are clearly referenced in Maureen Duffy's A thousand capricious chances: a history of the Methuen list 1889-1989, no citation is made of use of the company's own historic archives throughout the text itself, apart from a passing reference in her preface to her "constant raids on [the] carefully maintained records" and to "the archives and file room at the company warehouse in Andover" (1989, p.ix).

There is clearly much research potential for fully researched and well-cited work on publishing history, particularly following recent mergers and acquisitions of most of the major British publishing houses in the last decades of the twentieth century. However, some such examples do exist to a limited extent, such as that of Hodder \& Stoughton by John Attenborough (1975). Although precise sources are not cited throughout the text, they are nevertheless given to some degree in the acknowledgements. (It is ironic that this is the history of a company which witnessed the destruction of much of its business archives during WW2.) Some attention now will be given to the types of literary and publishing archives which are potentially available to underpin such research and other scholarship relating to children's literature and book/publishing history.

\section{Defining Publishing and Literary Archives}

Publishing houses are private commercial concerns, operating today in a competitive global environment which now also encompasses e-publications. Literary papers relating to individual authors are similarly private in terms of creation and ownership, and are therefore just as vulnerable as publishing archives over time when compared to archive collections enjoying legal protection (eg public and manorial records).

Part of the difficulties associated with the archive collections of private publishing houses is their ambiguous and schizophrenic status. Are these collections to be regarded as commercial publishing archives (of short-term value and low prestige), and/or as literary archives (of long-term value and high prestige)? 
Factors shaping the survival and destruction of business, publishing and literary archives will now be considered as these are directly relevant when addressing the issue of the survival and availability of archives for use within children's literature research. Inevitably, researchers are restricted to utilising those primary archival resources which remain extant and accessible to the academic and practitioner communities working within the field of children's literature.

\section{Business archives}

Of all types of record creators, the commercial sector seems to have a particularly poor track record in good recordkeeping, displaying instead an almost exclusive concentration on present and future concerns and issues. Publishing archives are easily identifiable as belonging to a larger type of archive collections, namely those owned privately by commercial companies of all types. Here, responsibility for their preservation naturally lies with the company in question. Custody of a company's historic archive is a fairly straightforward matter as long as the firm in question retains its integrity and identity and remains committed to retaining its corporate and cultural memory in the shape of its heritage collections. Even if not easily accessible or catalogued, the long-term security of the archives on the original premises is typically assured.

However, problems may emerge when the original company is taken over or merges with another company, (sometimes one with a more prestigious reputation or history, sometimes without). Imprints or lists can also be sold off piecemeal to other companies, sometimes at a fast rate of change of ownership. At this point, the long-term preservation of the historic archive in question can become subject to threat, either to a due to lack of interest from the owner parent company or as a result of relocation or reorganisation of premises.

In a key article on recent trends in business archives, Collins (1992) observes that structural changes in the post-war UK economy have resulted in a boom and slump tendency during the 1970s and 1980s, accompanied by a radical shift from manufacturing to the service industry and to a 1980s boom in self-employment. Urban redevelopment schemes during the 1960s and 1970s have resulted in rising rents in central locations and rising costs of record storage, resulting in mass record destruction or poor levels of accommodation. Typically company archives are housed in redundant and leaking warehouses offering inadequate environmental controls, making them vulnerable to fire, flood and theft. The postwar surge in takeovers and mergers has resulted inevitably in a rationalisation of firms and premises (1992, p.119). These developments in the commercial world have a direct impact on the state of publishing archives and their sustainability. More recently, if no in-house archive is in place, collections are often stored off-site by third party companies who dedicate no or little development work to the collections in their custody, merely carrying out the most basic levels of records management and file retrieval.

As a result of such pressures in a commercial environment, often the bare minimum of core records are retained with very rudimentary assessments made as to the risks of retention versus disposal of records. Private business archives are not subject to any type of legislation which safeguards their longevity and completeness in permanent archival terms (apart from the obvious data protection, tax 
and other requirements which only apply to a small group of records for specific time periods). Typically, records are retained only for the length of their useful life within the functions of the company concerned with little consideration given to historical value or corporate memory contained with historic company archives.

As Ceeney remarks, although "archives may do many similar things... their role in society, function and purpose have been, and remain, radically different depending on the culture, context and parent body" (2008, p.58). Therefore, when the business function of a part of an archive collection expires, it immediately becomes extremely vulnerable, with its research and historical significance not assessed or appreciated. Quail notes "the steady destruction of material which leaves once substantial businesses with barely a wisp of primary evidence that they ever existed" (1997, p.49), with Freeth commenting on increasing numbers of companies discontinuing their provision of inhouse archives and instead regarding paper records and historical archives as a "dead weight, not an asset" (2000: 183-184). As Faraday succinctly sums up, only too often are archives regarded as "the 'nice to have' factor' (2007, p.5).

\section{Publishing archives}

Historical events sometimes have a direct impact on the survival of archive collections, including those relating to children's literature. The publishing industry is no exception. The location of London publishers in the heart of the City and their proximity to the Thames during WW2 proved a negative point during the Blitz, when the records of several houses were lost. These include Hodder $\&$ Stoughton, and Longman (whose premises were also destroyed by fire in the mid $19^{\text {th }}$ century), as well as early incoming letters of Chatto and Windus being salvaged as paper during WW1.

Disasters and other unusual circumstances excepted, even the most basic levels of recordkeeping do not seem to be guaranteed when considering the fate of many archives associated with major British publishing houses. Although little is known of how some current companies care for their historic archives in-house, it is evident that only a fraction of historical material is now available within the research domain, compared to the sheer bulk of collections which must have existed at a prior point in time.

What exactly makes up this 'bulk' of paperwork generated within the average business over a prolonged period? Core records are typically preserved in the long-term to some degree, as their existence is essential for the daily running of the firm. In the publishing context, these would typically be board minutes, annual reports, annual accounts, staff records, publishing contracts etc. Records with a shorter shelf life such as editorial/author and publicity files and correspondence are more susceptible to being destroyed once their intended in-house use has come to an end, although this may depend on the status of the author in question. Manuscripts and drafts are also typically only retained in the very short term, which is of particular concern when for example examining translation and editorial practice in detail. Difficulties in establishing an editorial trail for documents edited entirely within the electronic medium (ie 'born digital') also create problems for the potential researcher (see below). 
The ownership of one or several publishing lists or imprints can commonly be assigned to another publishing company, with few of the established twentieth century publishers retaining their complete independence. Often in this situation, which has become increasingly frequent due to late twentieth century publishing mergers, the relevant files are not transferred to the new owners, but are retained by the predecessor company or even destroyed. Entire collections can be and have been thrown out on a whim, often with no deposit opportunity given to neighbouring archival repositories who might have an interest in preserving all or some of the materials for future scholarship.

Very few even of the largest publishing houses have invested in the services of a professional archivist or librarian. One notable exception is Oxford University Press, where a busy in-house library and a small professional archival team provide access to their sizable publishing collections, including those relating to children's literature. Similarly, Random House and Faber respectively employ a librarian and an archivist who work to support the work of the companies as well as fielding external enquiries to a limited degree. Unfortunately these three firms are unfortunately very much in the minority, as several publishing firms do not appear to have an archivist on their staff at all. Therefore, many major UK firms are not able or willing to provide access at all to their historic archives.

Another problem within publishing archives is that of the small press whose archives are particularly vulnerable. A common and parochial misconception within this sector seems to be that the firm's records are only of use or interest to those directly associated with the firm itself. For example, the archives of the specialist Welsh language publisher Gwasg y Dref Wen are apparently still extant but are retained privately, with no obvious intention to safeguard their long-term future at a suitable place of deposit such as the National Library of Wales. However small the press, their archives are directly relevant to my $\mathrm{PhD}$ topic, as they published a number of Swedish children's books in Welsh over a number of years. A different approach was taken by Floris Books in Edinburgh, the major publisher of Scottish fiction for children and also a specialist in European picture books. Here no paper files have been retained from its early days of establishment during the 1970s and it seems unlikely that research access would be granted if they had indeed survived. These examples both demonstrate the difficulty that both owners and potential curators of collections can have in assessing historical and research significance of publishing records.

One such individual who has been able to grasp this fully is the author and editor Aidan Chambers, who elected to deposit his entire holdings of literary and publishing papers with an approved repository, first at the University of Reading and latterly at the University of Aberystwyth. Prominent publishing archives can and do benefit from a good level of care within a research-led professional library and archival environment. The internationally significant John Murray archive was recently acquired by the National Library of Scotland, a recognised centre of collecting within the area of Scottish publishing, whose collections include that of Oliver and Boyd and William Blackwood. 
Similarly, many prominent English publishing archives are held at the University of Reading, where many English publishing houses are represented strongly. This strength of collecting policy has been actively pursued since the 1960s, as "it seemed appropriate that a... centre for English publishers might be set up within easy reach of London, where most of the major houses were located, and without poaching on ground staked out by other specialist repositories" (Bott 1992, p.439). As Edwards comments further, "the University of Reading's initiative in founding the archive was simply the local expression of a general sense that publishers' records have been strangely neglected by historians of literature and learning” (1979, p.30). Suitable staff expertise, building on that of the first archivists Jim Edwards and Michael Bott, exists to support the full exploitation of the collections despite sizable cataloguing backlogs. The quality of the publishing and printing archives is recognised by the Designated status of the collections awarded by the Museums Libraries and Archives Council.

Alternatively, as for the archives of children's literature mentioned above, some publishing archives are held regionally due to connections with a particular locality. For example the Penguin Archive is homed at the University of Bristol (the hometown of its founder Allen Lane) and the Blackie and Collins archives are held at the University of Glasgow. Similarly the Thomas Nelson collection is held at the University of Edinburgh. The London Metropolitan Archives' collections relating to the City of London also contain many publishing archives, including that of Hodder \& Stoughton.

In general terms, the obvious preference is for the information professional to be given the opportunity to work with publishers and authors in order to select the historic material which will be preserved permanently in the future. Only too often, valuable collections are thrown away by those not appreciative of its research significance and without the skills to appraise it appropriately. Fortunately, literary archives have a somewhat higher status within British culture, which has the direct result of a significantly higher survival rate of collections into the long-term.

\section{Literary archives}

Literary archives in the traditional sense comprise papers relating to the writing and publication of works of literature. These typically relate to a specific author (or illustrator), and are varied in nature, covering all stages of the writing process. They can include preparatory notes; handwritten, typescript and digital manuscripts; proofs; contracts, blurbs; correspondence/emails; press cuttings and promotional material; photographs; sound and TV recordings; lecture and speech notes; illustration drafts and proofs etc. Blogs, podcasts and other digital and social media can also now be included, although their definition and scope are less clear as yet. Depending on the nature of the collection and the individual concerned, personal papers may also be included within a literary collection, as well as papers relating to other spheres of an author's life (eg the archive of Aidan Chambers includes literary and personal papers as well as those relating to his interests in education and literacy, and to the many editorial positions that he has held).

Literary collections relating to specific authors and illustrators are often held in individual or family hands. Literary archives are usually the private property of the author or subsequent literary estate 
and, as for publishing archives, are similarly not protected by archival legislation. As personal and family circumstances alter over time, changes in the ownership and integrity of the collection may occur eg parts of the collection may be deposited in an institution or sold off during the creator's lifetime, at the time of their death or subsequently by their family or literary estate. Destruction is also an unfortunate possibility. As literary fashions change, a once well-known author can become unfashionable and their archives are therefore at risk of being thrown out by overzealous/careless heirs or simply forgotten in an attic.

The fate of a collection can depend on the profile and reputation of the author in question. Literary archives often enjoy a higher status than publishing archives, with universities and other institutions sometimes in open competition to purchase or acquire collections relevant to their existing holdings. These are then marketed as a unique selling point for the institution in question, and are exploited variously as an inspiration for research, teaching and outreach projects. . If a collection does become available to a UK research institution, increasing competition (particularly in the Higher Education sector) can occasionally outweigh the remit of existing collection policies, which are designed to define the type of collection in which a particular repository specialises and which additionally serve as a practical means to restrict unprofessional 'poaching' of collections between similar institutions. Ideally and indeed as is often the case, librarians and archivists can and do spend years nurturing relations with a potential donor so that very good relations are built up in the life time of the author or publishing individual concerned. This work in collection development can contribute very positively to securing the permanent preservation of a suitably significant collection.

It could be argued that publishing archives and particularly editorial files are regarded by many as constituting literary archives, partly as they may contain manuscripts and other papers relating directly to literary creations. However, often this is because publishing archives contain autograph letters from the authors concerned: when an author is or becomes high selling or prominent, the items acquire an indisputable market value as the collection in question becomes a desirable cultural and literary commodity. If sufficiently prestigious or high-profile within the field of English Literature, UK repositories may struggle to raise sufficient funds to purchase significant collections at market value.

Such collections may be sold to overseas' research institutions or split up and sold at auction. Two such collections of major UK publishers J M Dent and Andre Deutsch are now held in US university library research collections, primarily due to the undisputed literary and commercial value of the authors represented within the firms' publishing lists. This situation creates obvious obstacles for UK researchers undertaking research into these houses. However, the significantly higher level of archival investment available in many US university libraries does result in excellent online catalogues and a much reduced cataloguing backlog. 


\section{Challenges of Digital Archives}

Issues of digital preservation and modern means of communication are challenging the traditional paper-based curatorial and commercial recordkeeping environments in the UK and beyond. With all types of tasks of personal and commercial business now carried out usually through born-digital media such as email and Microsoft Office, such electronic data is extremely vulnerable to deletion or accidental loss. Considerable investment in electronic record management infrastructure and professional expertise is necessary to provide adequate safeguards for transferring relevant items into secure and permanent storage. It is suspected that many British publishing houses are failing in this respect at the current time, with staff costs at a premium and information/heritage professionals sometimes regarded as a 'luxury'. The often cited 'information black hole' of the late 1990s and 2000 s is by no means an exaggeration, with many major companies struggling to maintain access to core records created during this period.

If companies have a poor record for managing electronic or born-digital records (even with large IT departments and perhaps with records managers or other information professionals on hand), the situation for individually managed electronic records originating from authors or other literary bodies is more concerning. Floppy disks, computers/laptops and hard-drives in obselete formats can render entire collections of literary data entirely inaccessible and irretrievable to the creating author and to potential curators. Additionally, constant developments in technology result in the need for regular data migrations to new current formats even after the material has been deposited in an archival repository.

This is a challenge for a large archival institution and nearly impossible in a small repository with few staff and IT resources. As a whole, the British archive and records management professions have been slow to meet the challenges of creating and using suitable off-the-shelf collection management systems for such digital and electronic records. This situation has been amplified by the absence of strong leadership in this specialist area by the UK's national archives and libraries, resulting in curatorial apathy and ambivalence. Regrettably, this means in practice that digital literary and publishing archive collections created at the turn of the $21^{\text {st }}$ century are not being properly preserved, catalogued or managed from their time of deposit into permanent preservation. However, some national guides on professional best practice in the area have begun to emerge in the last couple of years.

\section{Professional Standards and Strategic Developments}

It seems that this perilous state of affairs is perhaps beginning to change for the better, albeit it at a leisurely pace. As has been seen throughout this paper, there is a clear divide between universally accepted standards of archival best practice and the actual reality of the long-term preservation and access of historical literary and publishing archives. However, well-established UK standards do exist which act as a guide for best practice for existing practitioners and for those responsible for the care and cataloguing of archive collections in more general terms. The British archival and record management sectors are predominantly populated by qualified professionals who are well 
placed to take up the challenges of curating publishing and literary collections. Very recent national developments relating to both business archives and to literary archives are also to be regarded very positively, with benefits for practitioners and future researchers.

Many of the problems facing the long-term survival of literary and publishing archives are starting to be pro-actively addressed and tackled in the UK through the auspices of the Group for Literary Archives and Manuscripts (GLAM). ${ }^{1}$ This was established in 2005 to bring together those with interests in the collecting, preservation, use and promotion of literary archives and manuscripts in Britain and Ireland. The group represents the interests of literary collections throughout the UK held in a wide range of institutions, varying from the custody of the British Library and other major research institutions to private individuals or trusts. A major undertaking has been the 2006/7 Survey of Collecting Policy and Practice, with work on cataloguing guidelines for literary manuscripts also underway. Unfortunately the planned comprehensive survey of literary collections held nationally does not yet appear to have been undertaken, although the University of Reading is from 2012 taking the lead in a three year project 'Diasporic Literary Archives' which will investigate the changing nature of literary manuscript culture in a global context. ${ }^{2}$ Similarly since 2005, the UK Literary Heritage Working Group: Collecting Modern Literary Archives has been addressing issues such as the dispersal of British literary manuscripts abroad taxation and the possible implementation of tax incentives to benefit living authors. ${ }^{3}$

The strategic environment for business archives in the UK is also improving. A National Strategy for Business Archives (England and Wales) was launched in July 2009, followed by the National Strategy for Business Archives in Scotland in January 2011. ${ }^{4}$ These strategies seek to promote business collections to firms, researchers and information professionals alike. The work of the Business Archives Council and the Business Archives Council Scotland also promote positive use of historic collections within a specifically commercial setting.

\section{Archives and Children's Literature Research in the Future}

It is still much too early for any such strategies and funding sources to have trickled downwards to the benefit of archivists and curators on the ground, although all of these recent developments are to be welcomed and encouraged. Now that the first steps have been taken to address curatorial issues relating to literary and publishing archives, much work still to be done to ensure that these collections, including those relating specifically to children's literature, are preserved and actively used as a research resource into the long-term.

This paper began by introducing children's literature archives in the UK and considering their national distribution. The visibility and use of publishing and literary archives within children's literature research was also examined, including publishing house company histories. Given the low use of publishing and literary archives in research into children's literature, some attention was given to the nature of business, publishing and literary archives (including digital collections) and to factors shaping collection dispersal and survival and their availability to researchers. Finally, recent developments in strategy and professional standards were outlined. 
This paper has raised some of the inherited, current and future issues facing those wishing to undertake research using British children's literature archives. It is hoped that it will also encourage researchers, practitioners and information professionals alike to enter into a more substantial debate on the challenges of collecting and preserving literary and publishing archives, as well as inviting interested parties to dip into the rich and largely untapped written heritage relating to British children's literature.

\section{Endnotes}

${ }^{1}$ See Group for Literary Archives and Manuscripts. Available from: http://glam-archives.org.uk/ [Accessed 18 March 2012]

${ }^{2}$ See Reading University Blog. Diasporic Literary Archives. Available from: http://blogs.reading.ac.uk/diasporic-literary-archives/ [Accessed: 18 March 2012]

${ }^{3}$ See UK Literary Heritage Group. Available from: www.literary.org.uk [Accessed: 18 March 2012]

${ }^{4}$ See The National Archives. National Strategy for Business Archives (England and Wales). Jul 2009. Available from: http://www.businessarchivescouncil.org.uk/materials/national_ strategy_for_business_archives.pdf [Accessed: 18 March 2012]. See also Business Archives Council Scotland. National Strategy for Business Archives in Scotland. Jan 2011. Available from: www.gla.ac.uk/services/archives/bacs/nationalstrategyforbusinessarchives/ [Accessed: 18 March 2012]

\section{References}

Attenborough, J. (1975) Living Memory: Hodder and Stoughton Publishers 1868-1975. London, Hodder and Stoughton.

Baines, P. (2010) Puffin by Design: 70 Years of Imagination 1940-2010. London, Allen Lane.

Bott, M. (1992) 'The archive of British publishers at Reading University Library', Leipziger Jahrbuch zur Buchgeschichte 2, 439-448.

Ceeney, N. (2008) 'The role of a $21^{\text {st }}$-century National Archives: the relevance of the Jenkinsonian tradition, and a redefinition for the information society', Journal of the Society of Archivists $29,1,57-71$.

Chester, T. (1989) Children's Books Research: A Practical Guide to Techniques and Sources. Stroud, Thimble Press.

Chester, T. (1989) Sources of Information About Children's Books. Stroud, Thimble Press.

Collins, E. (1992) 'Recent trends in business archives: a university view', Journal of the Society of Archivists 13, 2, 119-123.

Denman-West, M. (1998) Children's Literature: A Guide to Information Sources. Englewood, Libraries Unlimited.

Dudley Edwards, O. (2007) British Children's Fiction in the Second World War. Edinburgh, Edinburgh University Press.

Duffy, M. (1989) A Thousand Capricious Chances: A History of the Methuen List 1889-1989. London, Methuen. 
Edwards, J. (1979) 'Publishers' archives at Reading University’, Business Archives 45, 27-30.

Eliot, S. \& Owen, W. (eds) (1999) A Handbook to Literary Research. London, Routledge.

Faraday, J. (2007) 'Doing the business: the promotion of business archives in the private sector', Business Archives 93, 1-13.

Freeth, S. (2000) 'Business archives at Guildhall Library: new developments', Journal of the Society of Archivists 21, 2, 183-197.

Grenby, M. \& Reynolds, K.. (eds) (2011) Children's Literature Studies: A Research Handbook. Palgrave Macmillan, London.

Hannah, L. (2008) 'Business archives and the life cycle of the business historian', Business Archives 97, 13-18.

Holman, V. (2008) Print for Victory: Book Publishing in England 1939-1945. London, British Library.

Pearson, R. (2008) 'Missing pieces, or the difficulty of business history', Business Archives 97, 1926.

Penguin Books. (1985) Fifty Penguin Years. Harmondsworth, Penguin.

Quail, J. (2007) 'Business archives of large UK companies: survivals and prospects', Business Archives 94, 49-58.

Sousa Carrea, D. Da \& Owens, W. (eds) (2010) Handbook to Literary Research. London, Routledge.

\section{SOCR}

\section{Biographical Note}

Charlotte Berry is a registered archivist and curator with over 10 years of professional experience in a range of archives and heritage collections across England, Wales and Scotland. Particular specialisms are business, family and literary archives. She is completing a part time $\mathrm{PhD}$ at the University of Edinburgh, provisionally titled 'Publishing, translation, archives: Nordic children's literature in the UK from 1950'. 